Pengaruh Konsentrasi Glukomanan dan Waktu Proofing - Adiluhung, dkk Jurnal Pangan dan Agroindustri Vol.6 No.4: 26-37, Oktober 2018

\title{
PENGARUH KONSENTRASI GLUKOMANNAN DAN WAKTU PROOFING TERHADAP KARAKTERISTIK TEKSTUR DAN ORGANOLEPTIK ROTI TAWAR BERAS (Oryza sativa) BEBAS GLUTEN
}

\section{Effect of Glucomannan Concentration and Proofing Time on Texture and Organoleptic Characteristics of Gluten-Free Rice (Oryza sativa) Bread}

\author{
Westra Dwipa Adiluhung*, Aji Sutrisno \\ Jurusan Teknologi Hasil Pertanian, FTP Universitas Brawijaya Malang \\ JI. Veteran, Malang 65145 \\ *Penulis korespondensi, email: westra.dwipa@gmail.com
}

\begin{abstract}
ABSTRAK
Tepung beras sebagai bahan baku roti tawar bebas gluten memiliki keterbatasan dalam menahan gas karbondioksida $\left(\mathrm{CO}_{2}\right)$ dari hasil fermentasi. Glukomannan ditambahkan untuk membentuk lapisan film tipis menahan gas $\mathrm{CO}_{2}$ dan proofing berperan pada pengembangan volume roti yang mempengaruhi tekstur. Penelitian ini bertujuan untuk mengetahui konsentrasi glukomannan dan waktu proofing yang tepat sehingga menghasilkan karakteristik tekstur dan organoleptik yang baik. Desain Penelitian yang digunakan adalah Rancangan Acak Kelompok (RAK) faktorial, terdiri dari dua faktor yaitu konsentrasi glukomanan $(0,0.5,1 \%)$ dan waktu proofing $(30,60,90$ menit). Data dianalisis menggunakan analisis ragam (ANOVA) dengan uji lanjut Beda Nyata Terkecil (BNT) atau Duncan's Multiple Range Test (DMRT). Berdasarkan hasil penelitian, penambahan glukomannan tidak memberikan pengaruh yang nyata. Waktu proofing berpengaruh nyata $(\alpha=0.05)$ terhadap volume pengembangan spesifik, kekerasan dan elastisitas. Terjadi interaksi signifikan $(\alpha=0.05)$ antara glukomannan dan waktu proofing pada Kecerahan $\left(L^{*}\right)$. Perlakuan terbaik diperoleh pada konsentrasi glukomannan $1 \%$ dan waktu proofing 60 menit.
\end{abstract}

Kata kunci: Glukomannan, Proofing, Roti Tawar Bebas Gluten, Tepung Beras

\section{ABSTRACT}

Rice flour as gluten-free bread material had limitations in retaining carbon dioxide $\left(\mathrm{CO}_{2}\right)$ from the fermentation. Glucomannan was added to form thin film layer that hold $\mathrm{CO}_{2}$ as well as develop bread volume, thus affect texture of the bread. This study aims to determine glucomannan concentration and proofing time to produce good texture and organoleptic characteristic. Experimental design used Randomized Block Design (RBD) factorial, consist of two factors: glucomannan concentration (0, 0.5, 1\%) and proofing time (30, 60, 90 minutes). Data were analyzed using analysis of variance (ANOVA) with further test Least Significant Difference (LSD) or Duncan's Multiple Range Test (DMRT). The addition of glucomannan had no significant effect. Proofing time had significant $(\alpha=0.05)$ on specific volume development, hardness and elasticity. Interaction occurs significantly $(\alpha=0.05)$ between glucomannan and proofing time on brightness $\left(L^{*}\right)$. The best treatment was obtained at $1 \%$ glucomannan concentration and 60 minutes of proofing time.

Keywords: Glucomannan, Gluten Free Bread, Proofing, Rice Flour

\section{PENDAHULUAN}

Pertumbuhan pasar industri roti Indonesia rata-rata gabungan tahun 2010-2015 sebesar $13.3 \%$ dengan konsumsi $2.3 \mathrm{~kg}$ per kapita diiringi dengan kenaikan sebesar $6.23 \%$ yang menawarkan peluang pertumbuhan yang tinggi (Anonymous, 2016). Roti tawar 
konvensional terbuat dari gandum memiliki kandungan gluten yang dapat menyebabkan gangguan fungsi pencernaan (celiac disease). Alternatif yang dapat dilakukan adalah dengan menggunakan tepung bebas gluten salah satunya adalah tepung beras (Lopez et al., 2004). Tepung beras sebagai salah satu bahan baku roti bebas gluten memiliki keterbatasan dalam menahan gas karbondioksida $\left(\mathrm{CO}_{2}\right)$ dari hasil fermentasi (Rosell dan Marco, 2008). Hidrokoloid konjac glukomannan ditambahkan untuk membentuk lapisan film tipis menahan gas $\mathrm{CO}_{2}$ (Thomas, 1997). Selain itu waktu proofing juga berperan pada pengembangan volume roti yang mempengaruhi tekstur (Park et al., 2008; Choi, 2010). Penelitian ini bertujuan untuk mengetahui konsentrasi glukomannan dan waktu proofing yang tepat sehingga menghasilkan karakteristik tekstur dan organoleptik roti tawar bebas gluten yang baik.

\section{BAHAN DAN METODE}

\section{Bahan}

Bahan baku pembuatan roti bebas gluten adalah tepung beras (Rose Brand), glukomannan, ragi instant (Fermipan), gula tebu (Gulaku), garam halus (Cap Kapal), putih telur bubuk, susu skim, minyak nabati, air.

\section{Alat}

Alat yang digunakan dalam pembuatan roti bebas gluten adalah timbangan analitik (Camry model EK3250), mixer (Kirin model KHM-286), loyang alumunium ukuran 15x7x5cm, oven pemanggangan (Maspion).

Alat yang digunakan untuk analisis diantaranya CT3 Texture analyzer Brookfield Engineering Labs, Inc. dengan software TexturePro CT V1.4 Build 17, timbangan analitik (Denver Instrument M-310), oven listrik $220 \mathrm{~V}$ (Memmert), lemari asam, alat destruksi, alat destilasi (Buchi K-350), pemanas listrik $300 \mathrm{~W}$ (Maspion); stop watch, desikator (Nalgene), tanur listrik $600^{\circ} \mathrm{C}$ (Thermolyne), kertas saring halus, soxhlet (Gerhardt), kapas steril, benang wol, corong plastik, spatula besi, spatula kaca, cawan porselen, bola hisap (Sicherheits), colorimeter (Konica Minolta); pemegang buret, vortex, spektrofotometer dan scaning elecron microscope (Hitachi model TM3000) dan glassware yang mendukung.

\section{Desain Penelitian}

Rancangan percobaan yang digunakan adalah Rancangan Acak Kelompok (RAK) faktorial, terdiri dari dua faktor yaitu konsentrasi glukomanan $(0,0.5,1 \%)$ dan waktu proofing $(30,60,90$ menit) dengan 9 kombinasi perlakuan yang diulang tiga kali sehingga diperoleh 27 satuan percobaan. Data yang diperoleh kemudian dianalisis secara statistik dengan menggunakan ANOVA (Analysis of Variance) pada taraf kepercayaan 5\%. Apabila terdapat pengaruh nyata pada interaksi kedua perlakuan, dilakukan uji lanjut menggunakan DMRT (Duncan Multiple Range Test) dengan taraf kepercayaan 5\%. Apabila tidak terdapat interaksi namun di salah satu perlakuan atau keduanya terdapat pengaruh nyata, maka dilakukan uji BNT (Beda Nyata Terkecil) dengan taraf kepercayaan 5\%. Penentuan perlakuan terbaik dilakukan dengan menggunakan metode multiple attribute (Zeleny, 1982).

\section{Tahapan Penelitian}

Pembuatan Roti Tawar Bebas Gluten dengan modifikasi dari metode Park et al. (2014). Bahan baku adonan ditimbang dan diukur sebesar 0, 0.5, dan 1 gram glukomannan sesuai dengan perlakuan, $100 \mathrm{~g}$ tepung beras, $10 \mathrm{~g}$ gula, $1 \mathrm{~g}$ garam, $1.5 \mathrm{~g}$ ragi, $3 \mathrm{~g}$ putih telur bubuk, $3 \mathrm{~g}$ susu skim, $8 \mathrm{ml}$ minyak sayur dan $100 \mathrm{ml}$ air suhu ruang. Bahan adonan dimasukkan ke dalam baskom dimana ragi tidak mengalami kontak langsung dengan gula atau garam. Tahap berikutnya adalah mixing dengan mixer pada kecepatan skala 1 selama 1 menit, selanjutnya pada skala 2 selama 30 detik dan dilanjutkan pada skala 3 selama 30 detik menghasilkan adonan batter. Loyang sebelumnya dioles dengan minyak sayur dan dimasukkan adonan batter. Loyang ditutup dengan penutupnya serta kain untuk menjaga suhu dan kelembaban. Proses proofing dilakukan selama 30, 60 dan 90 menit sesuai dengan perlakuan pada suhu $27^{\circ} \mathrm{C}$. Oven sebelumnya dipanaskan pada suhu $170^{\circ} \mathrm{C}$ selama 10 menit 
sebelum adonan akan dimasukkan. Ketika proses proofing berakhir penutup loyang dibuka dan dimasukkan kedalam oven selama 30 menit pada suhu $170^{\circ} \mathrm{C}$. Loyang dikeluarkan setelah pengovenan dan didinginkan selama 45 menit. Roti yang telah dingin dikeluarkan dari loyang lalu dianalisis.

\section{Prosedur Analisis}

Analisis bahan baku meliputi analisis kadar pati metode hidrolisis asam (Sudarmadji dkk, 2010) dan analisis kadar amilosa metode iodometri (Yuan et al., 2007). Analisis produk meliputi analisis warna $L^{*}, a^{*}, b^{*}$ (Yuwono dan Susanto, 1998), volume roti, analisis tekstur profil (kekerasan, elastisitas dan kohesivitas) dengan Brookfield CT3 Texture analyzer (Faridah, 2015) dan analisis organoleptik (SNI, 2006). Analisis perlakuan terbaik meliputi kadar air metode oven kering, kadar protein metode Kjeldahl, kadar abu metode pengabuan kering (AOAC, 1990), kadar lemak metode Soxhlet (SNI, 1992), kadar karbohidrat metode by difference (Lestari dkk., 2013) dan mikrostruktur dengan Scanning Elcetron Microscopy (SEM) (Fleming dan Sosulski, 1978).

\section{HASIL DAN PEMBAHASAN}

\section{Analisis Bahan Baku}

Kandungan pati dari tepung beras yang digunakan adalah $77.7 \%$ yang tersusun oleh amilosa dan amilopektin sebesar $27.71 \%$ dan $49.99 \%$. Pati merupakan biopolimer yang menyediakan gula yang dapat difermentasi oleh yeast dan memiliki pengaruh signifikan pada rheology adonan terutama selama pengovenan (Cauvain, 2003). Pada proses pemanasan granula pati menyerap air pada media dan mengembang (swelling). Rantai amilosa lepas ke fase aqueous intergranular, menyebabkan peningkatan viskositas yang berlanjut hingga temperatur konstan yang mengarah kepada kerusakan fisik dari granula, juga diikuti dengan penurunan viskositas. Selama pendinginan roti, amilosa yang lepas dari granula pati oleh proses gelatinisasi pati selama pemanasan mengalami pengkristalan ulang. Molekul pati saling berikatan kembali terutama amilosa, menyebabkan formasi stuktur gel (Rosell, 2011).

Tabel 1. Perbandingan Data Analisis dan Literatur tepung beras

\begin{tabular}{ccc}
\hline \multicolumn{1}{c}{ Parameter } & Hasil Analisis & Data Literatur \\
\hline Pati (\% bk) & $77.7 \pm 0,78$ & $80.11^{\mathrm{a}}$ \\
Amilosa (\% bk) & $26.32 \pm 0,19$ & $25.46^{\mathrm{a}}$ \\
Ukuran Partikel (mesh/ $\mu \mathrm{m})$ & $80 / 180$ & $80^{\mathrm{b}}$ \\
\hline Sumber : ${ }^{\mathrm{a}}=$ Ferng et al. $(2016)$ & &
\end{tabular}

$\mathrm{b}=$ Badan Standarisasi Nasional (1995)

Amilopektin merupakan polimer yang memiliki banyak cabang dari pada amilosa dengan struktur yang linier, akan tetapi amilosa menjadi indikator dari kualitas pemasakan. Pati beras yang rendah akan amilosa bersifat waxy atau lengket (glutinous). Kandungan amilosa beras bersifat waxy lebih rendah $(<1 \%)$ dibanding dengan beras non-waxy $(>10 \%)$ (Rosell dan Marco, 2008). Tepung beras dengan amilosa yang tinggi baik untuk pembuatan roti (Kang, et al., 1997; Kang dan Han, 2000). Pada penelitian pendahuluan penggunaan tepung rendah amilosa (tepung ketan) menghasilkan roti dengan karakteristik buruk dilihat dari struktur crumb yang tidak menyerupai roti dimana berbentuk gel lengket tanpa pori.

Ukuran partikel dari tepung beras yang didapatkan adalah sebesar 80 mesh atau 180 $\mu \mathrm{m}$. Tepung beras dengan ukuran partikel kecil $(<150 \mu \mathrm{m})$ menghasilkan karakter roti yang lebih baik dibandingkan dengan partikel besar $(<355 \mu \mathrm{m})$ (Song dan Shin, 2007). De La Hera et al. (2014) melaporkan roti tawar bebas gluten yang terbuat dari tepung beras kasar dengan ukuran partikel antara 132 hingga $200 \mu \mathrm{m}$ lebih baik dalam volume pengembangan dan tekstur crumb dibandingkan dengan tepung beras halus dengan ukuran partikel $<132 \mu \mathrm{m}$, dimana nilai hidrasi adonan sebesar $90-110 \%$. 


\section{Analisis Fisik}

Tabel 2. Hasil Analisis Fisik Roti Tawar Beras Bebas Gluten

\begin{tabular}{|c|c|c|c|c|c|}
\hline \multirow[b]{2}{*}{ Perlakuan } & \multirow[b]{2}{*}{ Taraf } & \multicolumn{4}{|c|}{$\begin{array}{r}\text { Hasil Analisis } \\
\end{array}$} \\
\hline & & $\begin{array}{l}\text { Vol. Pengembangan } \\
\text { Spesifik }(\mathrm{g} / \mathrm{ml})\end{array}$ & $\begin{array}{c}\text { Kekerasan } \\
(\mathrm{g})\end{array}$ & $\begin{array}{l}\text { Elastisitas } \\
\quad(\mathbf{m m})\end{array}$ & Kohesifitas \\
\hline \multirow{3}{*}{$\begin{array}{l}\text { Konsentrasi } \\
\text { Glukomannan }\end{array}$} & $0 \%$ & $3.25^{\mathrm{a}}$ & $147.03^{a}$ & $2.64^{a}$ & $0.94^{a}$ \\
\hline & $0.5 \%$ & $3.39^{a}$ & $146.72^{a}$ & $2.75^{a}$ & $0.88^{a}$ \\
\hline & $1 \%$ & $3.29^{a}$ & $162.94^{\mathrm{a}}$ & $3.01^{a}$ & $0.92^{a}$ \\
\hline \multirow{3}{*}{$\begin{array}{l}\text { Waktu } \\
\text { Proofing }\end{array}$} & 30 menit & $2.78^{a}$ & $239.20^{a}$ & $2.80^{\mathrm{ab}}$ & $0.90^{a}$ \\
\hline & 60 menit & $2.79^{a}$ & $133.70^{b}$ & $2.56^{b}$ & $0.88^{a}$ \\
\hline & 90 menit & $3.25^{\mathrm{b}}$ & $83.80^{c}$ & $3.04^{a}$ & $0.95^{a}$ \\
\hline \multicolumn{2}{|c|}{ Kontrol } & - & 105.90 & 2.60 & 0.86 \\
\hline
\end{tabular}

\section{Volume Pengembangan Spesifik}

Hasil analisis ragam menunjukkan bahwa waktu proofing memberikan pengaruh yang nyata $(\alpha=0.05)$ terhadap nilai volume spesifik produk, sedangkan penambahan konsentrasi glukomannan tidak memberikan pengaruh yang nyata. Hal ini diduga karena gas yang terbentuk tidak dapat ditahan dengan baik karena struktur gelnya lemah. Glukomannan merupakan polisakarida non gelatin yang tidak dapat membentuk struktur jaringan yang utuh (Huang et al., 2007). Interaksi antara kedua faktor tidak memberikan pengaruh yang nyata.

Durasi waktu proofing yang panjang dapat meningkatkan nilai volume pengembangan spesifik produk. Hal tersebut diduga karena pembentukan karbondioksida $\left(\mathrm{CO}_{2}\right)$ oleh yeast membutuhkan waktu untuk memberikan hasil yang optimal. Proofing merupakan proses fermentasi dimana yeast menguraikan karbohidrat dan menghasilkan gas $\mathrm{CO}_{2}$ sehingga adonan dapat mengembang. Metabolit lain yang terbentuk selain gas $\mathrm{CO}_{2}$ adalah alkohol yang bersifat volatil yang membantu pengembangan dan memberi aroma khas roti, serta terbentuk asam yang memberi rasa dan membentuk panas (Santoni, 2009). Menurut Siffring dan. Bruinsma (1993) adanya penambahan waktu proofing dapat meningkatkan volume pengembangan adonan. Berdasarkan penelitian Moore et al. (2004) yang menggunakan waktu proofing selama 30 menit memperoleh volume spesifik $2.08 \mathrm{~g} / \mathrm{ml}$, dan Park et al. (2014) menggunakan waktu proofing selama 60 menit diperoleh volume spesifik kontrol $4.14 \mathrm{~g} / \mathrm{ml}$, dimana dapat menjelaskan bahwa lamanya waktu proofing dapat memberikan pengaruh kepada volume pengembangan spesifik.

Gambar 1 menunjukkan lama durasi waktu proofing menyebabkan peningkatan volume roti serta peningkatan ukuran pori-pori sel. Hal tersebut diduga karena adanya aktifitas metabolisme ragi menghasilkan gas $\mathrm{CO}_{2}$, dimana semakin lama waktu proofing maka gas yang dihasilkan semakin banyak untuk meningkatkan volume roti. Pori yang membesar diduga karena adanya peningkatan jumlah gas $\mathrm{CO}_{2}$ yang mampu ditahan oleh adonan. Pada kenampakan visual perlakuan proofing selama 30 menit menunjukkan bentuk menyerupai kubah pada bagian atas roti yang tidak ditemukan pada perlakuan 60 dan 90 menit, diduga karena struktur sel yang terbentuk kurang kuat sehingga mengempis tidak membentuk tekstur kubah. Peningkatan konsentrasi glukomannan menyebabkan keseragaman pori yang diduga karena glukomannan membentuk lapisan film tipis pada adonan secara homogen. 

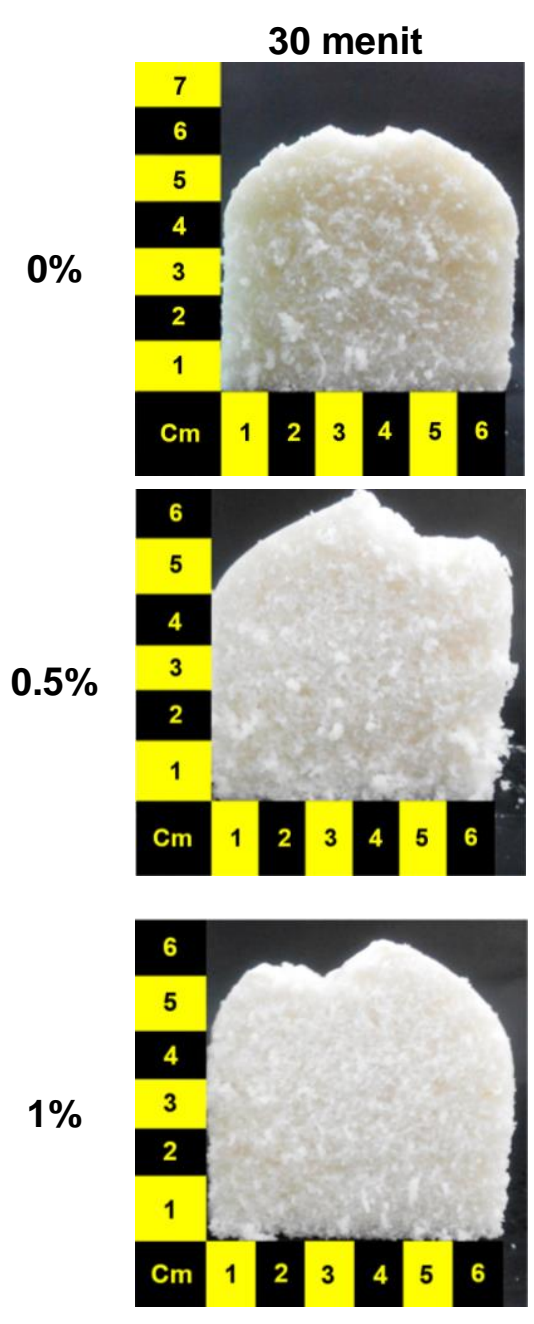
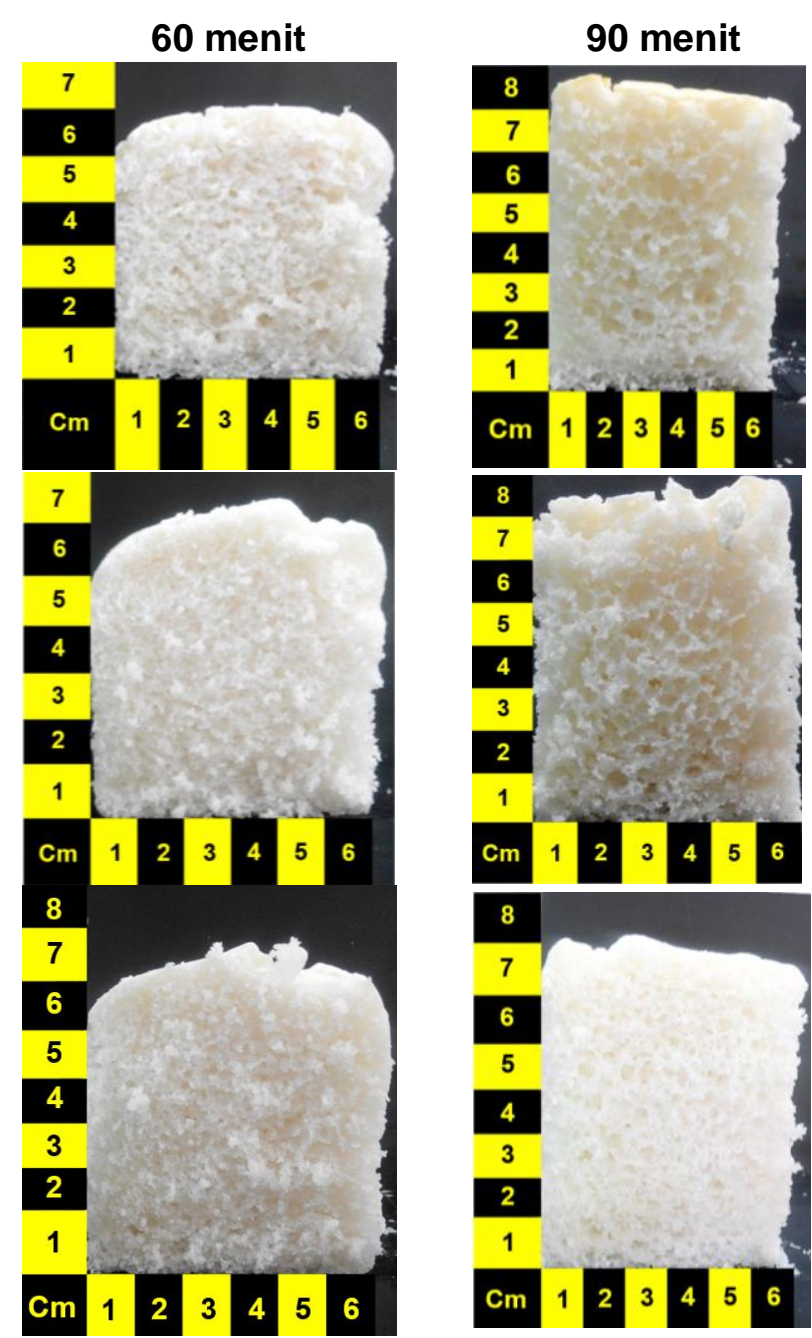

Gambar 1. Kenampakan Volume Roti Tawar Beras Bebas Gluten oleh Perlakuan Konsentrasi Glukomannan dan Waktu Proofing

\section{Kekerasan}

Kekerasan merupakan salah satu sifat fisik yang menentukan kualitas dari roti tawar dimana dapat menentukan kekuatan internal dari produk. Nilai kekerasan diperoleh dari puncak gaya yang diberikan pada siklus awal kompresi oleh instrumen analisis tekstur.

Hasil analisis ragam menunjukkan bahwa waktu proofing memberikan pengaruh yang nyata $(\alpha=0.05)$ terhadap nilai kekerasan produk. Sedangkan penambahan konsentrasi glukomannan tidak memberikan pengaruh yang nyata. Hal ini disebabkan karena glukomannan merupakan polisakarida non-gelatin yang tidak dapat membentuk struktur jaringan yang utuh sehingga hanya sedikit mempengaruhi terhadap nilai kekerasan (Huang et al., 2007). Interaksi antara kedua faktor tidak memberikan pengaruh yang nyata.

Data menunjukkan bahwa semakin lama waktu proofing maka nilai kekerasan menurun. Tren yang sama juga ditemukan pada penelitian Karimi et al. (2012) dimana ada penurunan nilai kekerasan pada produk yang signifikan karena pengaruh lamanya waktu proofing. Waktu proofing yang panjang menyebabkan peningkatan volume roti yang mana dapat mempengaruhi nilai kekerasan dari roti. Kekerasan dari roti secara signifikan menurun seiring dengan meningkatnya volume roti dan juga sebaliknya (Park et al., 2008; Choi, 2010). Diduga semakin lama waktu proofing rongga yang terbentuk relatif besar sehingga tekstur lebih lembut. Volume roti yang tinggi menghasilkan lapisan tipis antar sel gas sehingga produk semakin lembut (Ozmutlu et al., 2001). 


\section{Elastisitas}

Elastisitas merupakan tingkat ketinggian roti yang dapat kembali setelah kompresi diantara siklus kompresi pertama dan awal siklus kompresi kedua. Hasil analisis ragam menunjukkan bahwa waktu proofing memberikan pengaruh yang nyata $(\alpha=0.05)$ terhadap nilai elastisitas produk. Sedangkan penambahan konsentrasi glukomannan tidak memberikan pengaruh yang nyata. Glukomannan tidak mempengaruhi elastisitas dimungkinkan karena adanya pemisahan fase struktural antara gel pati beras dengan glukomannan (Huang et al., 2007). Interaksi antara kedua faktor tidak memberikan pengaruh yang nyata.

Waktu selama proofing 60 menit memberikan pengaruh terhadap nilai elastisitas, diduga karena pembentukan pori-pori tiga dimensi dimana ukuran pori menghasilkan sekatsekat dengan ketebalan tertentu yang dapat mempengaruhi elastisitas. Mir et al. (2016) menyatakan bahwa nilai kekerasan, kohesifitas dan elastisitas roti berkolerasi dengan porositas struktur internal, jumlah pori dan ukuran rerata pori. Ferng et al. (2016) juga menyatakan bahwa tipisnya sekat antar sel dapat menyebabkan struktur internal yang lemah dimana akan rusak ketika terkena kompresi.

\section{Kohesivitas}

Kohesifitas merupakan rasio kompresi siklus kedua dibagi dengan siklus pertama. Hasil analisis ragam menunjukkan bahwa perlakuan konsentrasi glukomannan dan waktu proofing tidak berpengaruh nyata terhadap nilai kohesivitas. Perlakuan tidak memberikan pengaruh yang signifikan diduga disebabkan oleh glukomannan yang merupakan polisakarida non-gelatin sehingga tidak dapat membentuk kohesifitas dan viskoelastik yang tinggi (Huang et al., 2007). Waktu proofing tidak berpengaruh terhadap nilai kohesifitas diduga karena struktur yang terbentuk tergantung dari komposisi yang digunakan. Martinez dan Gomez (2016) menunjukkan data roti bebas gluten berbahan baku tepung beras dengan hidrokoloid HPMC memiliki nilai kohesifitas 0.560 .

\section{Warna $\left(L^{*}, a^{*}, b^{\star}\right)$}

Data warna $L^{*}$ menunjukkan bahwa semakin lama waktu proofing maka nilai kecerahan menurun. Pada penambahan variasi konsentrasi glukomannan maka nilai kecerahan produk cenderung meningkat. Nilai kecerahan (L) tertinggi adalah 76.9 oleh perlakuan G3P1 (konsentrasi glukomannan 1\% dan waktu proofing 30 menit). Hasil analisis ragam menunjukkan bahwa konsentrasi glukomannan dan waktu proofing memberikan pengaruh yang nyata $(\alpha=0.05)$ terhadap nilai kecerahan produk. Data menunjukkan adanya interaksi antara kedua faktor.

Tabel 3. Hasil analisisn Kecerahan $\left(L^{*}\right)$ Roti Beras Bebas Gluten akibat Perlakuan Konsentrasi Glukomannan dan Waktu Proofing

\begin{tabular}{ccc}
\hline Konsentrasi Glukomannan (\%) & Waktu Proofing (menit) & Rerata kecerahan \\
\hline \multirow{2}{*}{0} & 30 & $75.4^{\mathrm{cd}}$ \\
& 60 & $71.2^{\mathrm{ab}}$ \\
\multirow{2}{*}{0,5} & 90 & $70.8^{\mathrm{a}}$ \\
& 30 & $75.6^{\mathrm{cd}}$ \\
\multirow{2}{*}{1} & 60 & $74.1^{\mathrm{bcd}}$ \\
& 90 & $73.5 \mathrm{a}^{\mathrm{bcd}}$ \\
& 30 & $76.9^{\mathrm{d}}$ \\
& 60 & $74.5^{\mathrm{cd}}$ \\
& 90 & $72.8^{\mathrm{abcb}}$
\end{tabular}

Keterangan: perbedaan notasi huruf pada tiap kolom menunjukkan pengaruh berbeda nyata $(\alpha=0.05)$.

Interaksi ini dikarenakan hidrokoloid yang ditambahkan secara umum terbukti dapat meningkatkan kecerahan crust (Sharadanant dan Khan, 2003; Lazaridou et al., 2007; Mandala et al., 2007; Shittu et al., 2009). Kecerahan didapat dari efek hidrokoloid terhadap distribusi air, yang berdampak pada reaksi Maillard dan kamarelisasi. Harzau dan Estiasih (2013) menyatakan reaksi Maillard diakibatkan oleh keberadaan protein yang cukup tinggi 
pada bahan adonan seperti susu skim dan putih telur, juga kandungan pati pada tepung beras serta adanya panas. Nilai kecerahan pada peningkatan waktu proofing diduga karena volume yang dihasilkan semakin tinggi yang menyebabkan kontak dengan sumber panas semakin meningkat, sehingga mengarah kepada reaksi Maillard memberikan warna emas kecoklatan (gelap) pada roti. Data yang didapat juga mengalami penurunan pada tingkat kecerahan terutama pada waktu proofing. Data serupa juga ditemukan pada Mandala et al. (2009) dimana adanya penurunan nilai $L^{*}$ yang bekerja dengan penambahan karagenan.

Data nilai kemerahan menunjukkan bahwa semakin lama waktu proofing maka nilai kemerahan cenderung meningkat. Pada penambahan variasi konsentrasi glukomannan nilai kecerahan produk cenderung meningkat pula. Namun penambahan variasi konsentrasi glukomannan dan lama waktu proofing tidak memberikan pengaruh yang nyata terhadap nilai kemerahan $\left(a^{*}\right)$.

Data nilai kekuningan menunjukkan bahwa semakin lama waktu proofing maka nilai kekuningan cenderung meningkat. Pada penambahan variasi konsentrasi glukomannan nilai kecerahan produk cenderung meningkat pula. Namun penambahan variasi konsentrasi glukomannan dan lama waktu proofing tidak memberikan pengaruh yang nyata terhadap nilai kekuningan $\left(b^{\star}\right)$.

\section{Analisis Organoleptik}

Uji organoleptik merupakan pengujian dengan menggunakan indra manusia sebagai alat ukur terhadap penerimaan suatu produk. Peran dari uji organoleptik sangat penting pada penerapan mutu produk. Uji organoleptik yang digunakan pada peneltian ini adalah uji hedonik dan uji skoring. Uji hedonik merupakan salah satu jenis uji penerimaan (acceptable test) terhadap suatu produk. Uji hedonik telah banyak dilakukan untuk mengukur tingkat kesukaan terhadap produk. Parameter yang diuji pada uji hedonik meliputi rasa, warna, aroma dan tekstur roti tawar bebas gluten dengan tingkat kesukaan berupa skala hedonik 1-7 (sangat tidak suka-sangat suka).
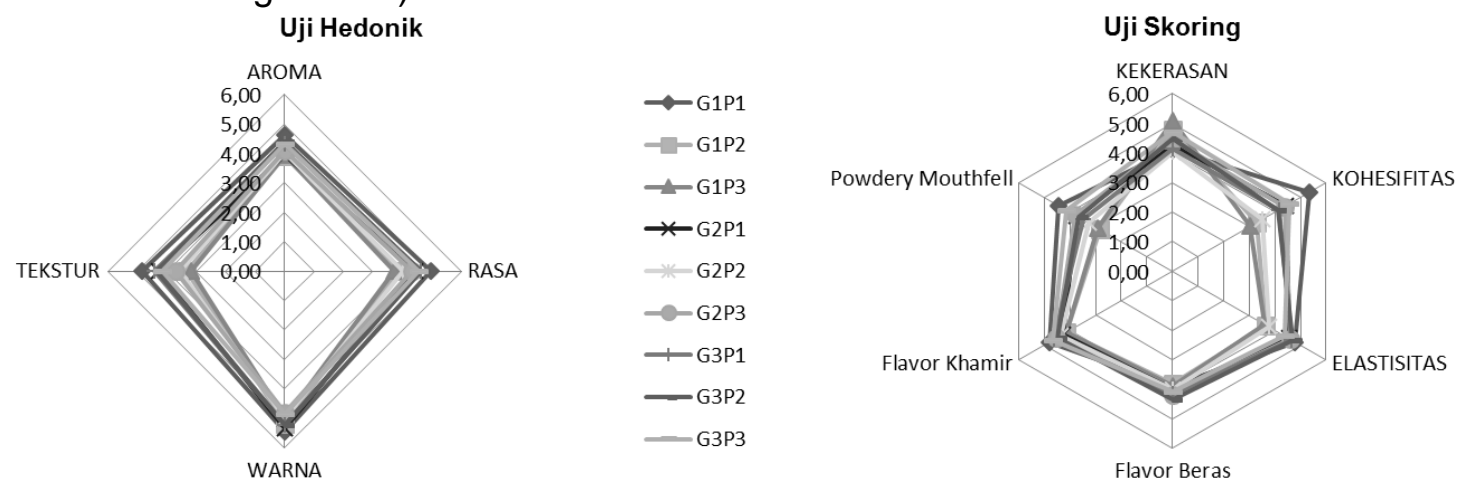

Gambar 2. Grafik Uji Organoleptik Roti Bebas Gluten Metode Skoring dan Hedonik Akibat Perlakuan Konsentrasi Glukomannan dan Waktu Proofing

Hasil analisis ragam menunjukkan bahwa perlakuan yang dilakukan berpengaruh nyata $(\alpha=0.05)$ terhadap semua parameter. Hasil analisis organoleptik uji hedonik pada roti tawar bebas gluten pada atribut aroma perlakuan $0 \%$ dan 30 menit (G1P1) merupakan hasil yang paling disukai. Parameter rasa perlakuan $0 \%$ dan 30 menit (G1P1) memiliki kesukaan tertinggi. Perlakuan warna yang disukai adalah perlakuan $0 \%$ dan 30 menit (G1P1). Tekstur roti yang disukai pada perlakuan $0 \%$ dan 30 menit (G1P1). Diduga tingkat kesukaan roti tawar dipengaruhi oleh reaksi metabolisme mikroba yang menghasilkan senyawa volatil yang menyebabkan pengembangan roti serta flavor, juga karakteristik roti bebas gluten yang khas dimana tingkat protein yang rendah yang mempengaruhi tekstur akhir.

Menurut Antara (2012) pada saat proofing terjadi pembentukan metabolit yang bervariasi seperti karbondioksida, etanol, asam laktat, asam asetat yang berdampak pada pengembangan volume yang juga mempengaruhi tekstur dari roti, flavor, warna serta umur simpan. Roti tawar bebas gluten memiliki beberapa kekurangan diantaranya rendahnya 
kemampuan adonan menahan gas yang dihasilkan pada saat proses proofing, sehingga roti yang dihasilkan memiliki tekstur crumb yang keras serta mudah mengalami stalling (Kuswardani dkk, 2008).

Uji skoring merupakan uji deskriptif dengan memberikan penilaian yang lebih spesifik pada suatu produk. Uji skoring dilakukan dengan pendekatan skala berupa skor yang dihubungkan dengan deskripsi atribut mutu produk tertentu. Nilai berupa angka digunakan untuk mengukur intensitas produk dengan susunan meningkat atau menurun. Parameter yang diuji berupa kekerasan, kohesifitas, elastisitas, flavor beras, flavor khamir dan powdery mouthfeel. Hasil analisis ragam menunjukkan bahwa perlakuan yang dilakukan berpengaruh nyata $(\alpha=0.05)$ terhadap semua parameter kecuali flavor beras. Hasil analisis organoleptik pada nilai kekerasan terbaik pada perlakuan $0 \%$ dan 90 menit (G1P3), kohesifitas pada perlakuan $0 \%$ dan 30 menit (G1P1), elastisitas pada perlakuan $0 \%$ dan 30 menit (G1P1), flavor beras pada perlakuan $1 \%$ dan 60 menit (G3P2), flavor khamir pada perlakuan $0 \%$ dan 30 menit (G1P1), dan powdery mouthfeel pada perlakuan 0\% dan 30 menit (G1P1). Powdery moutfeel yang tinggi diduga karena granula pati yang tidak berikatan baik dengan produk. Protein yang rendah menyebabkan lemahnya daya adesi antara protein dan granula pati sehigga tidak dapat berikatan dengan baik (Kang et al., 2015).

\section{Analisis Perlakuan Terbaik}

Perlakuan terbaik ditentukan menggunakan metode Multiple Atribute Zeleny. Atribut yang menjadi parameter perlakuan terbaik adalah uji fisik dan organoleptik. Pada penelitian ini roti bebas gluten yaitu pada konsentrasi glukomannan 1\% dan waktu proofing 60 menit (G3P2).

\section{Analisis Proksimat}

Tabel 4. Hasil analisis kimia roti bebas gluten

\begin{tabular}{cccc}
\hline Parameter \%bb & Hasil Analisis & SNI 01-3840-1995 & $\begin{array}{c}\text { Roti Gandum } \\
\text { (Malomo et al., 2011) }\end{array}$ \\
\hline Air & 34.88 & Maks. 40 & 33.51 \\
Protein & 5.66 & - & 11.07 \\
Lemak & 4.70 & Maks. 3 & 3.41 \\
Abu & 0.76 & Maks. 1 & 1.56 \\
Karbohidrat & 54.00 & - & 50.45 \\
\hline
\end{tabular}

Nilai kadar air roti tawar bebas gluten perlakuan terbaik sebesar $34.88 \%$ menunjukkan hasil yang sesuai dengan persyaratan SNI. Nilai kadar protein roti tawar bebas gluten perlakuan terbaik sebesar $5.66 \%$. Hasil tersebut menunjukkan hasil yang lebih rendah dari penelitian Park et al. (2014) dengan nilai 6.32\%. Hal tersebut dikarenakan adanya perbedaan jenis protein yang ditambahkan ditambahkan. Kadar lemak roti tawar bebas gluten perlakuan terbaik $(4.70 \%)$ menunjukkan hasil yang lebih tinggi dari yang disyaratkan SNI. Hal ini disebabkan oleh perbedaan bahan baku serta formulasi dari roti. Kadar abu roti tawar bebas gluten perlakuan terbaik $(0.76 \%)$ menunjukkan hasil yang sesuai dengan persyaratan SNI. Roti beras bebas gluten dengan hidrokoloid hydroxypropyl methylcellulose (HPMC) dan carboxymethyl cellulose (CMC) Park et al. (2014) memiliki kadar abu yang lebih rendah yaitu $0.25 \%$. Nilai kadar karbohidtrat roti tawar bebas gluten perlakuan terbaik sebesar $54.00 \%$. Segura dan Rosell (2011) meneliti sebelas macam roti bebas gluten dengan komposisi yang berbeda-beda, didapatkan rata-rata nilai kadar air sebesar $31.82 \%$, kadar protein rata-rata $4.83 \%$ (bk), kadar lemak rata-rata $11.05 \%$ (bk), kadar mineral rata-rata $2.94 \%$ (bk) dan karbohidrat toal rata-rata $81.18 \%$ (bk). Roti bebas gluten dengan roti gandum memiliki perbedaan mencolok pada kandungan protein. Perbedaan kandungan protein tersebut diduga karena gandum memiliki kandungan protein berupa gluten sebesar $24.9 \%$ yang tidak dimiliki oleh tepung beras (Malomo et al., 2011). 

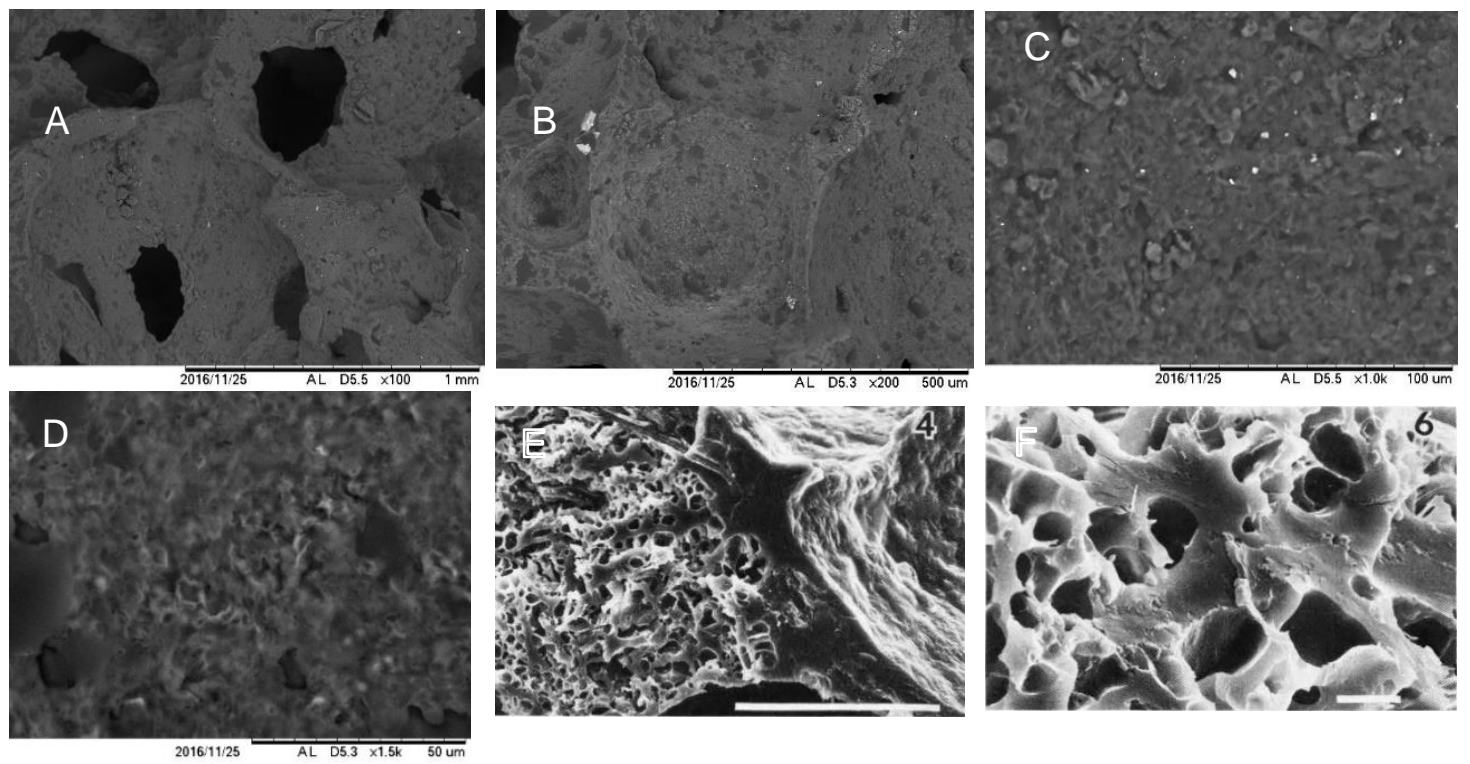

Gambar 3. Hasil Analisis Mikrostruktur Roti Tawar Bebas Gluten dan Gandum oleh Scanning Electron Microscop (SEM), A perbesaran 100x; B perbesaran 200x; C perbesaran 1000x; D perbesaran 1500x (dokumen pribadi); E bar $=100 \mu \mathrm{m} ; \mathrm{F}$ bar $=10 \mu \mathrm{m}$ (Pomeranz dan Meyer, 1984)

Gambar 3 menunjukkan dinding sel roti dengan ukuran diameter pori sebesar 0.1-0.4 $\mathrm{mm}$. Pada perbesaran yang lebih tinggi (Gambar $4.8 \mathrm{~B}$ ) terlihat pori dengan ukuran lebih kecil yang menyusun dinding sel dengan ukuran $100 \mu \mathrm{m}$. Gambar 4.8 C dan D menunjukkan jaringan halus seperti busa. Diduga terbentuk jaringan seperti busa oleh protein atau glukomannan yang mengikat granula pati. Peneitian Sayed dan Aal (2009) pada analisis SEM menunjukkan roti bebas gluten dengan formula beras, telur, susu, xantham gum dan HPMC memiliki matrik bikontinyu dengan fragmen pati yang mirip dengan gluten. Kombinasi pati dengan sebagian kecil hidrokoloid dan protein adalah dasar formasi dari tekstur crumb yang mirip dengan tekstur roti gandum. Roti gandum memiliki dinding sel yang lebih kecil (Gambar 4.8 E dan F) dibandingkan dengan perlakuan. Dinding sel roti gandum memiliki ketebalan rata-rata sebesar 2-5 $\mu \mathrm{m}$ dan terusun oleh beberapa lapis yang bergabung menjadi struktur komposit (Fleming dan Sosulski, 1978).

Arendt and Bello (2008) menunjukkan roti yang mengandung susu memiliki kualitas yang baik dan paling menyerupai roti berbahan baku tepung terigu. Roti yang mengandung susu memiliki kemampuan untuk membentuk jaringan seperti gluten. Protein yang dengan jumlah yang cukup dapat menjaga formasi dari fase kontinyu dan struktur film. Fase kontinyu dan struktur film dapat melindungi dari perubahan oleh retrogradasi pati yang mana menentukan kualitas dari roti bebas gluten. Penambahan polisakarida pada matrik protein memungkinkan peningkatan capaian mikrostruktur dengan fungsi yang berbeda. Pada penambahan konjak glukomannan dengan protein putih telur dapat meningkatkan kekerasan, chewiness dan elastisitas pada gel (Hu et al., 2016).

\section{KESIMPULAN}

Perlakuan penambahan konsentrasi glukomannan tidak memberikan pengaruh yang nyata terhadap karakteristik roti bebas gluten. Perlakuan variasi waktu proofing berpengaruh nyata $(\alpha=0.05)$ terhadap parameter volume pengembangan spesifik, kekerasan dan elastisitas. Terjadi interaksi antara penambahan variasi konsentrasi glukomannan dan waktu proofing pada parameter Kecerahan $\left(\mathrm{L}^{*}\right)$.

Perlakuan terbaik diperoleh pada konsentrasi glukomannan $1 \%$ dan waktu proofing 60 menit (G3P2) dengan karakteristik volume pengembangan spesifik $3.24 \mathrm{~g} / \mathrm{ml}$, warna $\left(\mathrm{L}^{*}\right) 74.5$, warna $\left(a^{\star}\right)-2.2$, warna $\left(b^{\star}\right) 9.0$, kekerasan $140.8 \mathrm{~g}$, elastisitas $2.47 \mathrm{~mm}$, kohesifitas 0.9 , kadar 
air $34.88 \%$ (bb), protein $5.66 \%$ (bb), lemak $4.7 \%$ (bb), abu $0.76 \%$ (bb) dan karbohidrat $54.0 \%$ (bb).

\section{DAFTAR PUSTAKA}

Antara, N.S. 2012. Pengendalian Proses Fermentasi dalam Pengolahan Roti. http://staff.unud.ac.id/semadiantara/wpcontent/uploads/2012/09/FermentasiRoti.pdf. Tanggal akses: 17/4/2016.

AOAC. 1998. Official Methods of Analysis of The Association of Official Analytical Chemists. Washington DC.

Badan Standarisasi Nasional. 1995. Standar Mutu Roti Tawar. SNI 01-3840-1995. Jakarta.

Cauvain, S. 2003. Breadmaking: Improving Quality. Woodhead Publisher. Cambridge.

Choi, I.D. 2010. Substitution of Rice Flour on Bread-Making Properties. Korean Journal of Food Preservative 17:5, 667-673.

Arendt, E., and Bello, F.D. 2008. Gluten-Free Cereal Products and Beverages. Academic Press. Massachusetts.

Anonymous. 2016. Konsumsi Per Kapita Masih Rendah, Saham Roti Prospektif. https://www.indopremier.com/ipotgo/newsDetail.php?jdl=Konsumsi_Per_Kapita_Masi h_Rendah_Saham_ROTI_Prospektif\&news_id=62316\&group_news=IPOTNEW'WSt aging_subtype=STOCK\&name=\&section=/ Tanggal akses: $7 / 4 / 2016$.

Faridah, H.M. 2015. Pengaruh Jumlah Air dan Jenis Hidrokoloid Terhadap Formula Roti Tawar Mini Bebas Gluten Berbasis Tepung Beras, Pati Jagung, dan Pati Singkong. Skripsi. Institut Pertanian Bogor. Bogor

Ferng, L.H., Liou, C.M., Yeh, R. dan Chen, S.H. 2016. Physicochemical Property And Glycemic Response of Chiffon Cakes with Different Rice Flours. Food Hydrocolloids 53: $172-179$

Fleming, S.E. dan Sosulski, F.W., 1978. Microscopic Evaluation of Bread Fortified with Concentrated Plant Proteins. Cereal Chemistry 55:3, 373-382.

Harzau, H. dan Estiasih, T. 2013. Karakteristik Cookies Umbi Inferior Uwi Putih (Kajian Proporsi Tepung Uwi: Pati Jagung dan Penambahan Margarin). Jurnal Pangan dan Agroindustri 1:1, 138-147.

de la Hera, E., Rosell, C.M., and Gomez, M. 2014. Effect of Water Content and Flour Particle Size on Gluten-Free Bread Quality and Digestibility. Food Chemistry 151: 526-531.

Hu, Y., Liang, H., Xu, W., Wang, Y., An, Y., Yan, X., Ye, S., Huang, Q., Liu, J. and Li, B., 2016. Synergistic Effects of Small Amounts of Konjac Glucomannan on Functional Properties of Egg White Protein. Food Hydrocolloid 52: 213-220.

Huang, M., Kennedy J.F., Li B., Xu X. dan Xie B.J. 2007. Characters of Rice Starch Gel Modified by Gellan, Carrageenan, and Glucomannan: A Texture Profile Analysis Study. Carbohydrate Polymers 69:3, 411-418

Kang, M.Y. and Han, J.Y. 2000. Comparison of Some Characteristics Relevant to Rice Bread Made from Eight Varieties of Endosperm Mutants between Dry and Wet Milling Process. Korean Journal of Food Science and Technology 32:1, 75-81.

Kang, M.Y., Sohn, H.M. and Choi, H.C. 1997. Varietal Variation in Gelatinization and Adaptability to Rice Bread Processing and Their Interrelation. Korean Journal of Crop Science. 42: 344-351

Kang, T.Y., Sohn, K.H., Yoon, M.R., Lee, J.S. and Ko, S. 2015. Effect of The Shape of Rice Starch Granules on Flour Characteristics and Gluten-Free Bread Quality. International Journal of Food Science and Technology. 50:8, 1743-1749.

Karimi, M., Fathi, M., Sheykholeslam, S., Sahraiyan, B., and Naghipoor, F. 2012. Effect of Different Processing Parameters on Quality Factors and Image Texture Features of Bread. Journal of Bioprocessing and Biotechnique 2:5, 4-10.

Kuswardani, I., Trisnawati, C.H. dan Faustine. 2008. Kajian Penggunaan Xanthan Gum Pada Roti Tawar Non Gluten yang Terbuat dari Maizena, Tepung Beras dan Tapioka. Jurnal Teknologi Pangan dan Gizi. 7:1, 55-65. 
Lazaridou, A., Duta, D., Papageorgiou, M., Belc N., and Biliaderis, C.G. 2007. Effects of Hydrocolloids on Dough Rheology and Bread Quality Parameters in Gluten Free Formulations. Journal of Food Engineering. 79:3, 1033-1047.

Lestari, L.A., Nisa' F.Z., dan Sudarmanto. 2013. Analisis Zat Gizi. Universitas Gadjah Mada. Yogyakarta.

Lopez, A.C.B., Pereira, A.J.G., and Junqueria, R.G. 2004. Flour Mixture of Rice Flour, Corn and Cassava Starch in the Production of Gluten-Free White Bread. Brazilian Archives of Biology and Technology. 47:1, 66-70.

Malomo, S.A., Eleyinmi, A.F. dan Fashakin, J.B. 2011. Chemical Composition, Rheological Properties and Bread Making Potentials of Composite Flours from Breadfruit, Breadnut and Wheat. African Journal of Food Science 5:7, 400- 410.

Mandala, I., Karabela, D. and Kostaropoulos, A. 2007. Physical Properties of Breads Containing Hydrocolloids Stored at Low Temperature. I. Effect of Chilling. Food Hydrocolloids $21: 8,1397-1406$.

Mandala, I., Polaki, A. and Yanniotis, S. 2009. Influence of Frozen Storage on Bread Enriched with Different Ingredients. Journal of Food Engineering 92:2, 137-145.

Martinez M.M., dan Gomez M. 2016. Rheological and Microstructural Evolution of The Most Common Gluten-Free Flours and Starches During Bread Fermentation and Baking. Journal of Food Engineering 197: 78-86.

Mir S.A., Shah M.A., Naik H.R. and Zargar I.A. 2016. Influence of Hydrocolloids on Dough Handling and Technological Properties of Gluten-Free Breads. Trends in Food Science and Technology 51: 49-57.

Moore, M.M., Schober, T.J., Dockery, P., dan Arendt, E.K. 2004. Textural Comparison of Gluten-free and Wheat Based Doughs, Batters and Breads. Cereal Chemistry 81:5, 567-575.

Ozmutlu O., Sumnu G., and Sahin S. 2001. Assessment of Proofing of Bread Dough in The Microwave Oven. European Food Research and Technology 212:4, 487-490.

Park M.K., Lee K.S. dan Lee K.H. 2008. Effect of Rice Powder Particle Size in Baked Rice Breads. Journal of The East Asian Society of Dietary Life 18: 397-404.

Park, J.H., Kim, D.C., Lee, S.E., Kim, O.W., Kim, H., Lim, S.T., dan Kim, S.S.. 2014. Effects of Rice Flour Size Fractions on Gluten Free Rice Bread. Food Science and Biotechnology 23:6, 1875-1883.

Pomeranz, Y., dan Meyer, D. 1984. Light and Scanning Electron Microscopy of Wheat and Rye-Bread crumb, Interpretation of Specimens Prepared by Various Methods. Food Microstructure 3: 159-164.

Rosell, C.M. 2011. The Science of Doughs and Bread Quality. Elsevier. pp 3-14.

Rosell, C.M., dan Marco C. 2008. Rice. Elsevier. pp 81-96.

Santoni. 2009. Tips Meningkatkan Mutu Roti. Foodreview Indonesia. 4:4

Sayed, E.M. dan Aal, M.A. 2009. Functionality of Starches and Hydrocolloids in Gluten-Free Foods. Blackwell Publishing. New Jersey.

Sharadanant, R., dan Khan, K. 2003. Effect of Hydrophilic Gums on The Quality of Frozen Dough: II. Bread Characteristics. Cereal Chemistry 80:6, 773-780.

Shittu, T.A., Aminu, R.A. and Abulude, E.O. 2009. Functional Effects of Xanthan Gum on Composite Cassava-Wheat Dough and Bread. Food Hydrocolloids 23:8, 2254-2260.

Siffring, K. dan Bruinsma, B. L. 1993. Effect of Proof Temperature on The Quality of Pan Bread. Cereal Chemistry 70:3, 351-353.

Song, J.Y. and Shin, M.S. 2007. Effects of Soaking and Particle Sizes on The Properties of Rice Flour and Gluten-Free Rice Bread. Food Science and Biotechnology 16: 759764.

Sudarmadji, S., Haryono, B., dan Suhardi. 2010. Prosedur Analisis untuk Bahan Makanan dan Pertanian. Liberty. Yogyakarta.

Thomas, W.R. 1997. Konjac Gum. Dalam Imeson, A. Thickening and Gelling Agents for Food. Springer. US. 
Pengaruh Konsentrasi Glukomanan dan Waktu Proofing - Adiluhung, dkk Jurnal Pangan dan Agroindustri Vol.6 No.4: 26-37, Oktober 2018

Yuan, Y., Zhang, L., Dai, Y., and Yu, J. 2007. Physicochemical Properties of Starch Obtained from Dioscorea Nipponica Makino Compared with Other Tuber Starches. Journal of Food Engineering 82:4, 436-442.

Yuwono, S., dan Susanto, T. 1998. Pengujian Fisik Pangan. Universitas Brawijaya. Malang Zeleny, M. 1982. Multiple Criteria Decision Making. McGraw-Hill. New York. 